\title{
Assessment of the Prevalence of Multidimensional Poverty in Nigeria: Evidence From Oto/ljanikin, Lagos State
}

Tope Shola Akinyetun, MSc.

Adeniran Ogunsanya College of Education, Oto/Ijanikin, Lagos State, Nigeria

(iD) https://orcid.org/o000-0002-1906-3410

Jamiu Abiodun Alausa, M.Ed.

Adeniran Ogunsanya College of Education, Oto/Ijanikin, Lagos State, Nigeria (iD https://orcid.org/oooo-0o02-5665-851X

Dare Deji Odeyemi, M.Ed.

Adeniran Ogunsanya College of Education, Oto/Ijanikin, Lagos State, Nigeria

iD https://orcid.org/oooo-0001-7534-6231

Aihonsu Samuel Ahoton, MSc.

Adeniran Ogunsanya College of Education, Oto/Ijanikin, Lagos State, Nigeria

iD https://orcid.org/oooo-0001-5580-9788

Contact: akinyetuntope@gmail.com

\section{Abstract}

Poverty in Nigeria is endemic and continues to deepen even amid economic growth. We found that, beyond income, Nigeria is faced with multidimensional poverty that involves healthcare, education, and living standards, with several indicators. Recently dubbed the poverty capital of the world, Nigeria faces an enormous challenge in combating multidimensional poverty. Our study, which was theoretically analyzed using social exclusion theory, adopts both qualitative and quantitative approaches to examine the extent of multidimensional poverty in Nigeria, with particular attention on Oto/Ijanikin, which is a semiurban suburb of Lagos State. Primary data were gathered from the study area, while secondary data were sourced on the prevalence of multidimensional poverty in Nigeria. Focusing on indicators such as healthcare, electricity, education, clean water, and housing, we conclude that multidimensional poverty is indeed widespread in Nigeria and, thus, we recommend social inclusion as the solution.

Keywords: multidimensional poverty, poverty, social exclusion, social inclusion

Date Submitted: March 19, 2021 | Date Published: July 29, 2021

\section{Recommended Citation}

Akinyetun, T. S., Alausa, J. A., Odeyemi, D. D., \& Ahoton, A. S. (2021). Assessment of the prevalence of multidimensional poverty in Nigeria: Evidence from Oto/Ijanikin, Lagos State. Journal of Social Change, 13(2), 24-44. https://doi.org/10.5590/JOSC.2021.3.2.03

Note: We acknowledge the editor and the anonymous reviewers for their useful suggestions in strengthening the manuscript. We also acknowledge Adewusi Sulaiman Sunday, Idowu Seun Michael, Aremu Ayodeji Lateef, and Adewusi Lukman Adeyemi who assisted in the data-gathering process and who acted as our research guides in the study area. 
Akinyetun et al., 2021

\section{Introduction}

Nigeria recently topped South Africa to become the largest economy in Africa (Naidoo, 2020) and one of the fastest-growing economies in the world, despite the prevailing recession (Oxfam International, 2017). Still, the country is characterized by a sheer inability to translate this economic progress into meaningful development. All poverty reduction programs remain utterly unresponsive to economic growth (World Bank, 2016). Beyond rhetoric, the poverty rate in the country can best be understood in terms of accurate figures, with 40.1\% (82.9 million) of the total population classified as poor (National Bureau of Statistics [NBS], 2020). The paradox here, therefore, is that even as the country's economy improves, the poverty rate soars.

According to Ajakaiye et al. (2014), Nigeria typifies a country that has had rapid economic growth but worsening poverty. Surprisingly, the theoretical arguments and empirical evidence from the literature that attribute poverty reduction to fast economic growth seem to be failing in the Nigerian context. As the World Bank (2016) notes, taking a cue from the growth elasticity of poverty, for every 1.0\% growth in GDP per capita, poverty declined by only $0.6 \%$. This unfortunate development has aroused serious questions, such as is Nigeria's wealth assessed by Nigerians' poverty? Are Nigerians poor because the country is rich?

Traditionally, poverty has been conceived from a monetary perspective such that people are categorized as poor according to their position on the specific poverty line, that is, $\$ 1.90$ a day in 2015 (Ferreira et al., 2015). The adequacy of this method in identifying "the poor," even though not in doubt, has become restrictive, giving its fixation on wealth and income as indicators of welfare (Sambe, 2019). So what happened to living standards and essential facilities such as healthcare, sanitation, and, most importantly, education? How do we classify a household that lives on more than a dollar a day but still finds it difficult to access these basic necessities? What happened to human welfare on the whole? Does living on more than a dollar or two a day indicate positive human welfare? These questions and their armchair answers show the limits of monetarybased measurements of poverty and call for an all-encompassing approach (non-monetary-based methods) to the study of poverty.

As we observed and reported, a large number of Nigerians are deprived of the most basic amenities, such as electricity, clean water, good housing facilities, healthcare, and education (Ogionwo, 2016). The purpose of our study was to assess multidimensional poverty in Nigeria to be able to make recommendations for the reduction of poverty in the country by tackling social exclusion. To identify the extent of multidimensional poverty in the area, we selected certain Multidimensional Poverty Index (MPI) dimensions (health, education, and living standard) with a specific focus on five indicators (access to health facilities, quality education, stable power supply, clean water, and housing/sanitation). We limited our study to Oto/Ijanikin, a suburb of Ojo Local Government Area of Lagos State. We assumed that multidimensional poverty is prevalent in that area and that a relationship exists between the age of the participants and the indicators of multidimensional poverty there. Our study, however, is not without limitations. The research was constrained by the participants' lack of interest in the data collection process. Moreover, due to the high level of illiteracy in the area, it was difficult to find the required number of participants as we needed participants who could read, write, and seamlessly interpret the items of the research instrument.

Despite these challenges, we found significance in several ways. By attempting to link multidimensional poverty with social exclusion, our study contributes to the academic debate on poverty studies. This is especially noteworthy in the case of Nigeria, which is presently the poverty capital of the world. Also, our study offers useful insights into the prevalence of multidimensional poverty in Nigeria through a primary investigation based on both quantitative and qualitative data. This is important as it will raise the consciousness of the Federal Government of Nigeria on the level of poverty and social exclusion in the country and, thus, evoke the initiation and implementation of relevant policies. Our study is also significant as it expounds on the relevance of social inclusion in engendering a society that guarantees unprejudiced access to 
favorable living standards. Therefore, our study is discussed under six subheadings: the introduction, theoretical framework, literature review, methods, discussion, way forward, and conclusion.

\section{Theoretical Framework}

\section{Social Exclusion Theory}

Social exclusion theory argues that some people in a society are often kept from achieving the benefits of economic and social impact. These people are denied access to the resources that are available to others in society. People in society who often fall into the social exclusion category include women, girls, and people from the lower echelons of society (Silver, 1994). The history of the concept is contestable as it has been traced to Aristotle (Sen, 2000) and Max Weber (Hills et al., 2002). However, its contemporary usage is credited to Rene Lenoir, who in 1974 was concerned with the exclusion of the social groups in France that had fallen from the protection of the welfare state (Rodgers et al., 1997). Social exclusion is multidimensional and incorporates a range of issues, such as poor public relationships, lack of access to employment, and the absence of a political voice (Khan et al., 2015). Social exclusion implies multidimensional disadvantage and multifarious deprivations (Room, 1995; Sen, 2000).

Dean (2016) opines that social exclusion emphasizes the process through which advantage is conferred on a person or group of persons and denied to others. Since the experience of poverty is individualistic (Law \& Shek, 2014), social exclusion theory is relevant in analyzing poverty in Nigeria because it looks at poverty from a multidimensional perspective by paying attention to the various dimensions of poverty. As noted and as our findings indicated, poverty in Nigeria is multidimensional; every box of the dimensions and indicators of multidimensional poverty is boldly ticked. As such, the theory captures deprivation concerning health, education, and living standard and in the indicators identified in the study: healthcare, education, electricity, water, and housing. In Nigeria, deprivation is neither restricted to gender, ethnic group, or religious affiliation nor to age or health status. As Birchall (2019) notes, social exclusion in Nigeria has no penchant for biological or psychological orientation; it is intersectional and impedes groups' participation in society.

\section{Literature Review}

Social exclusion in Nigeria is attributable to several factors, including corruption, inequality of the distribution of resources, gender inequality, lack of education for the poor, differences in economic opportunities in rural-urban communities, and unemployment. Khan (2012) observes that social exclusion is both a cause and an effect of inequality. Social exclusion results from ingrained inequality in employment, access to resources, public services, and education. This is particularly true in the case of Nigeria where religion and ethnicity have become the basis of resource acquisition, resource allocation, and resource sharing. This submission was echoed by Akinyetun and Bakare (2020) that ethnicity and religion are part of the most decisive factors upon which politics is based in Nigeria.

Regarding age and class, Akinyetun (2021) submits that the youth in Nigeria are predominantly excluded from governance and have become recurringly subjected to deprivation and marginalization, especially from political participation. Akinyetun further reiterates that the level of widespread unemployment, limited opportunities, and barriers to education remain a bane to social inclusion in Nigeria. Uzochukwu et al. (2020) stress that the drivers of social exclusion in Nigeria exist at macro, meso, and micro levels. At the macro level, exclusion results from power contestation, resource rivalry, sociocultural and religious crises, and developmental divides. At the meso level, social exclusion is attributable to lack of access to services, stereotypes, competition for resources, and institutional rules. At the micro level, social exclusion is a function of socioeconomic status and health-seeking behavior. 
Khan (2012) opines that social exclusion is also linked with conflict. That is, when not properly managed, conflict can deteriorate and marginalize a society. This is the case in the northeast parts of Nigeria where the Boko Haram insurgency has held sway for more than a decade. The menace has left thousands of people dead, destroyed properties, and displaced thousands of residents in the area. Indeed, since the insurgency intensified, the number of internally displaced persons in the region has increased, while poverty has been equally deeply rooted (Akinyetun et al., 2020). According to Ogionwo (2016), the causes of social exclusion in Nigeria are corruption, poor education, poverty, and terrorism. Ogionwo avers that corruption in Nigeria is well established and that public funds have been diverted that would otherwise have driven development. Corruption has led to inequality, poverty, marginalization, unemployment, illiteracy, and exclusion. In the same vein, the poor educational system in the country and its attendant structural defects have led to an increase in the number of illiterates who cannot actively contribute to society. Meanwhile, due to rising poverty, people have organized themselves and joined extremist groups to express their frustration against bad governance. This development has also increased the chances of terrorism in the country.

Nworgu and Nworgu (2013) add that the rural-urban disparity in Nigeria is yet another precursor to social exclusion. They argue that most rural areas in Nigeria are characterized by a lack of infrastructural facilities and denoted by pronounced geographical, social, economic, and political deprivations. These deprivations include lack of communication facilities, poor educational services, austere rural poverty, lack of safe drinking water, poor health services, poor sanitation, and poor road networks.

\section{Poverty}

Poverty is difficult to conceptualize as various scholars have given it a different meaning from different perspectives. The definition of poverty is often attached to its cultural and historical roots (Lister, 2004). As a multidimensional concept, poverty lends itself to various interpretations in development studies. Although often used to describe some level of social exclusion, deprivation, and inequality, poverty refers to the lack of personal, household, or communal needs, such as food, income, housing, etc., needed to maintain a standard of living (Momodou, 2016). Tiemann (1993) notes that the effects of social exclusion range among individuals, groups, and geographical areas. Social exclusion is not restricted to income; rather, its tentacles spread to health, education, and housing, etc. Social exclusion can be the cause and result of rising unemployment, ethnic tension, and a high level of poverty. With recourse to deprivation, Spicker (1993) avers that poverty not only refers to deprivation but also to sustained deprivation, that is, deprivation experienced over some time.

From the various appraised thoughts on poverty, it is apparent that poverty denotes lack and connotes deprivation. Our study, therefore, saw poverty as the state of economic exclusion, inequality, and sustained deprivation that subjects an individual, group, or community to lack and impedes them from assessing their basic needs required to guarantee positive well-being.

\section{Multidimensional Poverty}

Brück and Kebede (2013) state that multidimensional poverty allows measuring poverty using different variables. For instance, assessing poverty through literacy or tangible assets could be a more reasonable method that could also capture long-term poverty. Multidimensional poverty measures can be used to create a more comprehensive picture to reveal who is poor and how they are poor, that is, the range of different disadvantages they experience. Multidimensional measures can be broken down to reveal the poverty level in different areas of a country and among different subgroups of people (Multidimensional Poverty Peer Network [MPPN], n.d.). According to the Lagos Bureau of Statistics (LBS, 2016), multidimensional poverty is the approach to measuring poverty beyond monetary values. Poverty itself manifests in varied dimensions and, thus, should be studied as such. The poor may refer to people who are unable to own a home or whose living conditions might be unhygienic. The poor are unable to afford or access medical facilities, water, and electricity. They are exposed to environmental issues, poor infrastructure, poor health, illiteracy and 
ignorance, insecurity, as well as social and political exclusion. Generally, the poor are prone to lack of security, domestic violence, and indolence while being unable to access government utilities and services. However, for our study, they are categorized under lack of (a) healthcare, (b) power, (c) education, (d) water, and (e) housing.

\section{Multidimensional Poverty Index (MPI)}

According to United Nations Development Programme (UNDP, 2010), the MPI is the product of the multidimensional poverty headcount (the share of multidimensionally poor people) and the average number of deprivations each multidimensionally poor household experiences (the intensity of their poverty). It measures severe deprivations by mirroring the Human Development Index in the dimensions of health, education, and living standards, which are reflected in 10 indicators, each with equal weight within its dimension (see Table 1). A household is multidimensionally poor if it is deprived in two to six indicators. The MPI reveals the degree of poverty beyond monetary measures by capturing overlapping deprivations. The MPI is most appropriate for less developed countries. It captures the widespread deprivations in South Asia, Subsaharan Africa, and the poorest Latin American countries.

Table 1. Global MPI 2020-Dimensions, Indicators, Deprivation Cutoffs, and Weight

\begin{tabular}{|c|c|c|c|}
\hline $\begin{array}{c}\text { Dimensions } \\
\text { of Poverty }\end{array}$ & Indicator & Deprived If Living in a Household Where... & Weight \\
\hline Health $(1 / 3)$ & Nutrition & $\begin{array}{l}\text { Any person under } 70 \text { years of age for whom there is nutritional } \\
\text { information is undernourished. }\end{array}$ & $1 / 6$ \\
\hline \multirow[t]{2}{*}{$\begin{array}{l}\text { Education } \\
(1 / 3)\end{array}$} & $\begin{array}{l}\text { Years of } \\
\text { schooling }\end{array}$ & $\begin{array}{l}\text { No eligible household member has completed } 6 \text { years of } \\
\text { schooling. }\end{array}$ & $1 / 6$ \\
\hline & $\begin{array}{l}\text { School } \\
\text { attendance }\end{array}$ & $\begin{array}{l}\text { Any school-aged child is not attending school up to the age at } \\
\text { which they would complete class } 8 \text {. }\end{array}$ & $1 / 6$ \\
\hline \multirow{6}{*}{$\begin{array}{l}\text { Living } \\
\text { standards } \\
(1 / 3)\end{array}$} & $\begin{array}{l}\text { Cooking } \\
\text { fuel }\end{array}$ & $\begin{array}{l}\text { A household uses solid fuel, such as dung, agricultural crop, } \\
\text { shrubs, wood, charcoal, or coal for cooking. }\end{array}$ & $1 / 18$ \\
\hline & Sanitation & $\begin{array}{l}\text { The household has unimproved or no sanitation facility, or it is } \\
\text { improved but shared with other households. }\end{array}$ & $1 / 18$ \\
\hline & $\begin{array}{l}\text { Drinking } \\
\text { water }\end{array}$ & $\begin{array}{l}\text { The household's source of drinking water is not safe, or safe } \\
\text { drinking water is a 30-minute or a longer walk from home, } \\
\text { roundtrip. }\end{array}$ & $1 / 18$ \\
\hline & Electricity & The household has no electricity. & $1 / 18$ \\
\hline & Housing & $\begin{array}{l}\text { The household has inadequate housing materials in any of the } \\
\text { three components: floor, roof, or walls. }\end{array}$ & $1 / 18$ \\
\hline & Assets & $\begin{array}{l}\text { The household does not own more than one of these assets: } \\
\text { radio, TV, telephone, computer, animal cart, bicycle, motorbike, } \\
\text { or refrigerator, and does not own a car or truck. }\end{array}$ & $1 / 18$ \\
\hline
\end{tabular}

Source: OPHI (2018). 
Akinyetun et al., 2021

\section{Multidimensional Poverty in Nigeria}

Poverty remains endemic in Nigeria. The most recent official survey by the NBS puts the poverty headcount rate in 2009 to be $53.5 \%$ using the international poverty line of $\$ 1.90$ per person per day. The extreme poverty headcount rate for 2019 was projected to be $50.1 \%$, indicating a little improvement in the incomes of the poorest half of the population over the past decade (NBS, 2020). According to the African Development Bank (AfDB, 2015), poverty in Subsaharan Africa is pervasive and thus causes a low level of infrastructural development in the region. Nigeria contributed 26.2\% of Subsaharan Africa's poor as of 2010, with a poverty rate of 68.0\% from her total population (Amao et al., 2017). Alkire and Santos (2014) estimated that 71.2 million Nigerians are MPI poor; this represents 15.4\% of the total number of Subsaharan Africans considered MPI poor. The concern here, therefore, is that poverty in Nigeria has continued to grow from independence at an alarming rate. As Garba (2006) notes, only about $15 \%$ of 42 million Nigerians were poor when the country got its independence in 1960. As the population increased to about 147 million in 1980, the poverty level also

rose to about $28 \%$. It is imperative, therefore, to appraise the extent of multidimensional poverty in Nigeria to find a solution.

The Nigerian MPI shows a high incidence of poverty across the north, with the poorest states having more than $80 \%$ of their population classified as multidimensionally poor. The intensity of deprivation in the region is greater than $40 \%$ for most states, which means that the average household in these areas is deprived in just under half of the indicators. This is in stark contrast with the southern part of the country, especially the southwest, where both the incidence and intensity of poverty are much lower. According to the Nigerian MPI, the poorest states are Sokoto, Jigawa, and Yobe in the north, with MPI scores between 0.35 and 0.45 , while the least poor states are found in the southwestern part of the country with MPI scores ranging from 0.06 to 0.12. The big divide in poverty rates between the north and the south is caused by the higher concentration of drivers of poverty reduction in the south (educational attainment, demographic change, employment, location of residence, access to basic infrastructure, and productive assets). The disparity is not a feature of the last decade alone; indeed, the chasm has existed for many years in various socioeconomic indicators and economic opportunities (MPPN, 2018; UNDP, 2018; World Bank, 2016).

Using different poverty measures, such as food poor, absolute poor, relatively poor, and a dollar per day, available data reveal that the incidence of poverty in Nigeria is more pronounced in the north compared to the south (NBS, 2012). Poverty in Nigeria is more prevalent in the northern part of Nigeria, with Yobe having a poverty index of 0.635 compared to a state like Lagos with an index of 0.035 . This is complemented by the figures from the NBS, which indicate that with a $52.10 \%$ poverty rate, poverty is more widespread in the rural parts of Nigeria compared to the urban areas (NBS, 2020). Indeed, recent data from NBS (2020) show that aside from Ebonyi and Enugu states, all states above the national poverty average are from the north (i.e., Sokoto, Taraba, Jigawa, Adamawa, Zamfara, Yobe, Niger, Gombe, Bauchi, Nasarawa, Katsina, Kano, Plateau, Kebbi, and Kaduna).

\section{Multidimensional Poverty in Lagos State}

For our study, poverty in Lagos State was appraised to give an insight into the poverty level in the study area. According to the Lagos Bureau of Statistics (LBS, 2016), 9\% of Lagosians are illiterate, with $2 \%$ of school-age (2-17 years) children (i.e., preschool, primary, and secondary) out of school. However, the unemployment rate in Lagos is $15 \%$, with a Senatorial dispersion of $16 \%, 14 \%$, and $15 \%$ in Lagos West, Lagos Central, and Lagos East districts, respectively. The report also indicates that given the same Senatorial distribution, 8\%, $11 \%$, and $9 \%$ of household heads are unable to provide necessities to the members of their families on food, clothing, and shelter, respectively. While $10 \%$ of Lagosians live in partially completed and uncompleted buildings, $77 \%$ of Lagos residents are tenants, and 50\% of Lagosians still use an unconventional method of electricity (local lamp, kerosene, palm oil, Fitila, and candle). Furthermore, $4 \%$ of residents use

unconventional toilet facilities (pail bucket, flush gutter, dig the ground and bury, mobile bush/field, toilet on 
water) and $8 \%$ use open defecation. In the same vein, $15 \%$ of Lagosians use an unconventional source of water, which includes unprotected dug well, private tankers, small-scale truck vendors, lagoon, spring, local river, creek, dam, lake, stream canal, pond, irrigation channels, and rainwater. Meanwhile, 21\% of Lagosians still use unauthorized ways of disposing of their refuse (dumping ground in the neighborhood, truck pushers, within the compound, buried/burnt).

Having appraised the extent of multidimensional poverty in Lagos State, we then turned to assessing multidimensional poverty in the study area.

\section{Summary of Literature}

The literature review presented in this section began with an exploration of the causes of social exclusion in Nigeria. Factors such as corruption, inequality of the distribution of resources, gender inequality, lack of education for the poor, differences in economic opportunities in rural-urban communities, and unemployment were presented as the causes of social exclusion in Nigeria. This submission was substantiated with scholarly references that discuss social exclusion in Nigeria. Also, definitions of poverty and multidimensional poverty were reviewed in the literature with an attempt made to examine the MPI regarding its dimensions and indicators; multidimensional poverty in Nigeria was also reviewed. The literature also reviewed multidimensional poverty in Lagos State. This became necessary against the backdrop that, despite being more economically developed and having the highest Internally Generated Revenue in Nigeria, the level of illiteracy in the state is high. The discussion from this section revealed that Lagos State is bedeviled by outof-school children, uncompleted buildings, unconventional toilet facilities, and unclean water sources, among others.

\section{Research Questions}

1. What is the extent of multidimensional poverty in Oto/Ijanikin area of Lagos State?

2. What is the extent of multidimensional poverty in Oto/Ijanikin area of Lagos State according to age?

\section{Methods}

\section{Study Area and Data}

Oto/Ijanikin refers to the integration of two separate communities-Oto and Ijanikin into one in the OtoAwori Local Council Development Area (latitude: $6.4836^{\circ}$ and longitude: $3.1217^{\circ}$ ) under the Ojo Local Government Area (LGA) of Lagos State, Nigeria. Oto/Ijanikin is situated at the rear of Lagos along a major road that links Nigeria and the Republic of Benin. Located in the southwest of Lagos State, along LagosBadagry Expressway, Ojo LGA is $163 \mathrm{sq} \mathrm{km}$ and has a total population of 941,523 (LBS, 2017). Oto/Ijanikin was selected for several reasons: (a) the study area is the host community to our higher education institutionAdeniran Ogunsanya College of Education (AOCOED), which attracted our interest; (b) the observable incidence of poverty motivated us to embark on the study to identify the extent of multidimensional poverty in the area and to proffer practical solutions; (c) we wanted to verify that Nigerians living in border communities regularly face social exclusion and vulnerability because of their geographic remoteness, which makes public service provision and education levels far lower than elsewhere in the country (Le Van et al., 2019).

We used both primary and secondary data from our fieldwork and reports from government institutions, nongovernmental organizations, and scholarly works of academics contained in journals, conference papers, books, and newspapers. The primary data were purposively sourced from the residents of Oto/Ijanikin, spread across the five wards in the Local Council Development Area (i.e., two in Oto, two in Ijanikin, and one 
in AOCOED). Without an official record of the population of Oto/Ijanikin, since it is dominated by students of AOCOED whose residency is not permanent, we had to turn to the polling record, which shows that a total of 32,106 people registered as residents of Oto/Ijanikin; thus, this became the sample size. Applying the Taro Yamane formula with a $5 \%$ margin of error, the minimum sample required for the study was calculated:

$$
\mathrm{n}=\mathrm{N} /[1+\mathrm{N}(\mathrm{e} 2)]
$$

Where

$$
\begin{aligned}
& \mathrm{N}=\text { population } \\
& \mathrm{k}=\text { Constant }(1) \\
& \mathrm{e}=\text { degree of error expected } \\
& \mathrm{n}=\text { sample size }
\end{aligned}
$$

Using the formula, we obtained a minimum sample size of 395, and a simple random sampling technique was used to select these participants from various households in Oto/Ijanikin. Meanwhile, a structured questionnaire with two sections was employed to elicit data from the respondents, the percentage and crosstabulation of which were analyzed with Statistical Package for Social Sciences [SPSS v22]. The first section of the questionnaire requested demographic data from the participants, while the second section contained questions on the selected dimensions and indicators (healthcare, electricity, water, education, and housing) for testing multidimensional poverty in the study area.

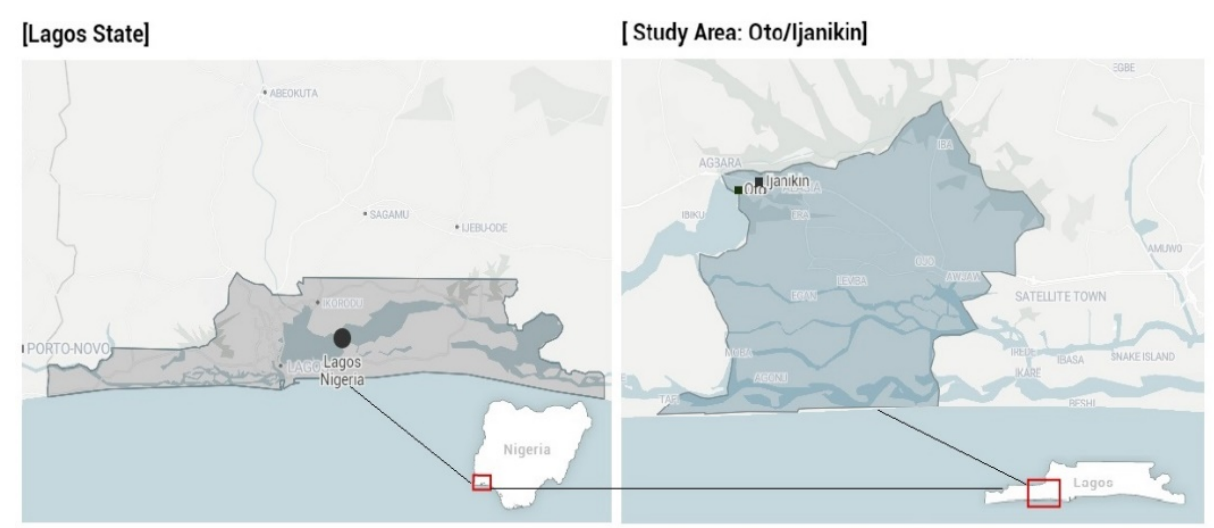

Figure 1: Study Area.

Source: Authors.

\section{Data Analysis}

The data were collected with a self-designed questionnaire entitled Multidimensional Poverty in Lagos State Questionnaire (MPILSQ), which contains two parts. Part I collected data on the participants' sociodemographic characteristics. Part II contained questions aimed at assessing the prevalence of multidimensional poverty in the study area with a 5 -point reverse-coded response scale $(1=$ absolutely untrue, $2=$ untrue, 3 = prefer not to say, $4=$ true, $5=$ absolutely true). The data gathered were subjected to nonparametric data analyses (i.e., Chi-square) on IBM SPSS v.22, at a significance level of $p \leq 0.0001$. Chisquare was selected because it provides robust information on how each group performs in the study and equips the researcher with more detailed information. Chi-square is also easy to compute and is flexible in handling data from two or more group studies (McHugh, 2013). 


\section{Results}

Our research questions served as the starting point for understanding the nature of social exclusion in Nigeria.

Table 2. Key Characteristics of Participants

\begin{tabular}{|l|l|l|}
\hline Characteristics & Frequency & Percentage (\%) \\
\hline Age & & \\
\hline $15-24$ & 44 & 11 \\
\hline $25-34$ & 231 & 59 \\
\hline $35-44$ & 99 & 25 \\
\hline 45 and above & 21 & 21 \\
\hline Total & $\mathbf{3 9 5}$ & $\mathbf{1 0 0}$ \\
\hline Gender & & \\
\hline Male & 200 & 51 \\
\hline Female & 195 & 49 \\
\hline Total & $\mathbf{3 9 5}$ & $\mathbf{1 0 0}$ \\
\hline Educational level & & \\
\hline Primary & 122 & 31 \\
\hline Secondary & 204 & 52 \\
\hline Postsecondary & 69 & 17 \\
\hline Total & $\mathbf{3 9 5}$ & $\mathbf{1 0 0}$ \\
\hline Employment status & & \\
\hline Employed & 97 & 25 \\
\hline Unemployed & 298 & 75 \\
\hline Total & $\mathbf{3 9 5}$ & $\mathbf{1 0 0}$ \\
\hline Location & & $\mathbf{1 0 0}$ \\
\hline Oto & 212 & 54 \\
\hline Ijanikin & 183 & $\mathbf{1 0 0}$ \\
\hline Total & $\mathbf{3 9 5}$ & $\mathbf{2 0}$ \\
\hline Residential area & & $\mathbf{2 0}$ \\
\hline Ring road & 79 & $\mathbf{2 0}$ \\
\hline Under bridge & 79 & \\
\hline AOCOED roundabout & 79 & \\
\hline Ile-oba & 79 & \\
\hline Mosalashi & 79 & \\
\hline Total & & \\
\hline
\end{tabular}

Source: Authors' research. 
Table 3. Multidimensional Poverty in Oto/Ijanikin Area of Lagos State

\begin{tabular}{lll} 
Indicators & Frequency & Percentage (\%) \\
\hline Access to healthcare services & & 13 \\
Yes & 53 & 87 \\
No & 342 & \\
\hline Access to a stable power & & \\
supply & 58 & 15 \\
Yes & 337 & 85 \\
No & & \\
\hline Access to quality education & 111 & 28 \\
Yes & 284 & 72 \\
No & & \\
\hline Access to clean water & 104 & 26 \\
Yes & 291 & 74 \\
No & & \\
\hline Access to good housing & 89 & 23 \\
Yes & 306 & 77 \\
No & & \\
\hline
\end{tabular}

Table 4. Crosstabulation of Age and Indicators of Multidimensional Poverty

\begin{tabular}{|c|c|c|c|c|c|c|c|c|c|c|c|}
\hline \multicolumn{12}{|c|}{ Indicators of Multidimensional Poverty } \\
\hline \multirow[t]{2}{*}{$\begin{array}{c}\text { Age } \\
\text { (years) }\end{array}$} & \multirow[t]{2}{*}{$*$} & \multicolumn{2}{|c|}{$\begin{array}{c}\text { Access to } \\
\text { health care } \\
\text { services }\end{array}$} & \multicolumn{2}{|c|}{$\begin{array}{c}\text { Access to a } \\
\text { stable } \\
\text { power } \\
\text { supply }\end{array}$} & \multicolumn{2}{|c|}{$\begin{array}{c}\text { Access to } \\
\text { quality } \\
\text { education }\end{array}$} & \multicolumn{2}{|c|}{$\begin{array}{l}\text { Access to } \\
\text { clean water }\end{array}$} & \multicolumn{2}{|c|}{$\begin{array}{c}\text { Access to } \\
\text { good housing } \\
\text { facilities }\end{array}$} \\
\hline & & Yes & No & Yes & No & Yes & No & Yes & No & Yes & No \\
\hline \multirow[t]{2}{*}{$15^{-24}$} & $\mathbf{O}$ & 4 & 40 & 6 & 38 & 15 & 29 & 25 & 19 & 6 & 38 \\
\hline & $\mathbf{E}$ & $5 \cdot 9$ & 38.1 & 6.5 & 37.5 & 12.4 & 31.6 & 11.6 & 32.4 & 6.5 & 37.5 \\
\hline \multirow[t]{2}{*}{$25-34$} & $\mathbf{O}$ & 35 & 196 & 29 & 202 & 76 & 155 & 58 & 173 & 29 & 202 \\
\hline & $\mathbf{E}$ & 31.0 & 200.0 & 33.9 & 197.1 & 64.9 & 166.1 & 60.8 & 170.2 & 33.9 & 197.1 \\
\hline \multirow[t]{2}{*}{$35-44$} & $\mathbf{O}$ & 8 & 91 & 23 & 76 & 20 & 79 & 21 & 78 & 23 & 76 \\
\hline & $\mathbf{E}$ & 13.3 & 85.7 & 14.5 & 84.5 & 27.8 & 71.2 & 26.1 & 72.9 & 14.5 & 84.5 \\
\hline \multirow{4}{*}{$\begin{array}{l}45 \text { and } \\
\text { above }\end{array}$} & $\mathbf{O}$ & 6 & 15 & 0 & 21 & o & 21 & o & 21 & O & 21 \\
\hline & $\mathbf{E}$ & 2.8 & 18.2 & 1 & 17.9 & 5.9 & 15.1 & 5.5 & 15.5 & 3.1 & 17.9 \\
\hline & $\mathbf{O}$ & 53 & 342 & 58 & 337 & 111 & 284 & 104 & 291 & 58 & 337 \\
\hline & $\mathbf{E}$ & 53.0 & 342.0 & 58.0 & 337.0 & 111.0 & 284.0 & 104.0 & 291.0 & 58.0 & 337.0 \\
\hline Total & & \multicolumn{2}{|c|}{395} & \multicolumn{2}{|c|}{395} & \multicolumn{2}{|c|}{395} & \multicolumn{2}{|c|}{395} & \multicolumn{2}{|c|}{395} \\
\hline
\end{tabular}

*Note: $\mathrm{O}=$ observed count, $\mathrm{E}$ = expected count. 


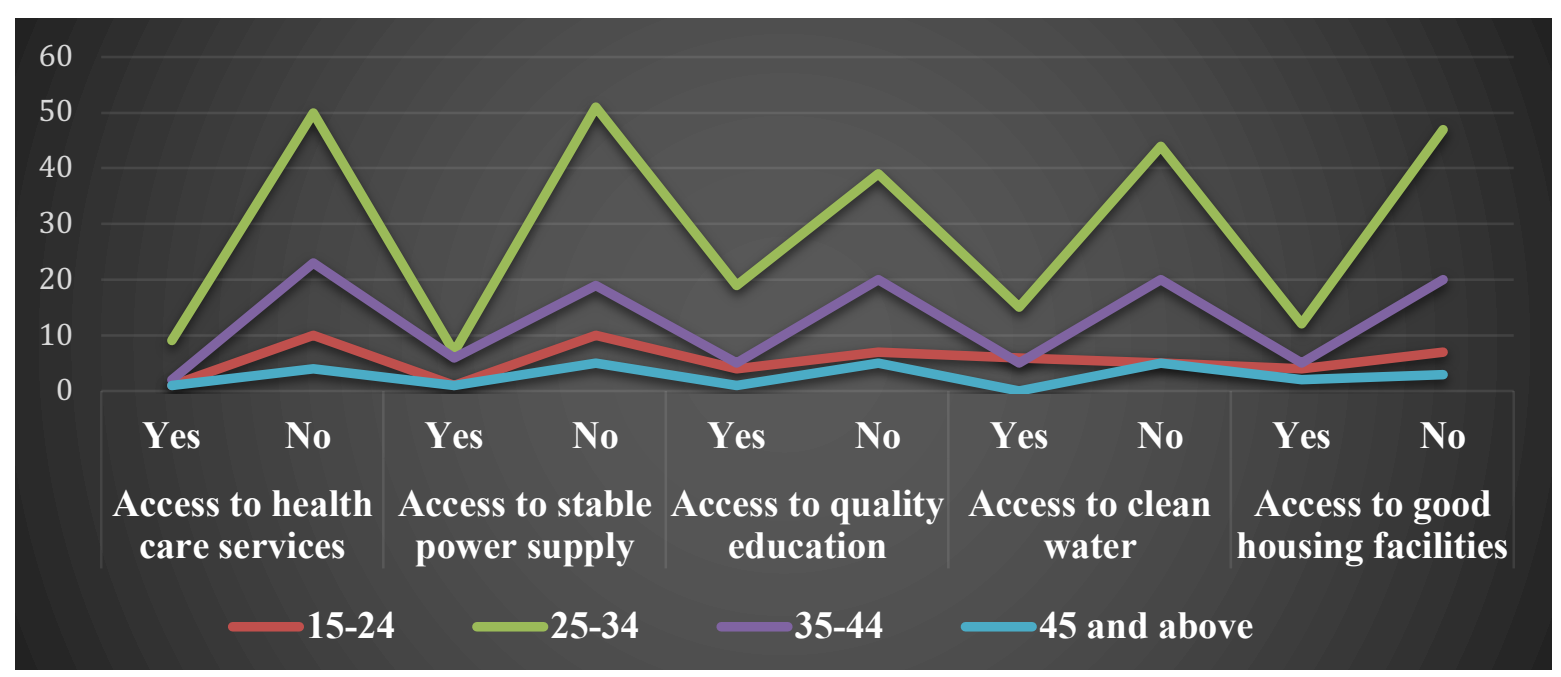

Figure 2. Crosstabulation of Age and Indicators of Multidimensional Poverty Source: Authors.

\section{Access to healthcare services}

To determine the relationship between age and access to healthcare services, a Chi-Square test was performed (Table 5). Age was significant for access to healthcare services $\left(\mathrm{X}^{2}=7.885, p \leq .0001\right)$.

\section{Access to stable power supply}

To determine the relationship between age and access to a stable power supply, a Chi-Square test was performed (Table 5). Age was significant for the access to a stable power supply $\left(\mathrm{X}^{2}=10.264, p \leq .0001\right)$.

\section{Access to quality education}

To determine the relationship between age and access to quality education, a Chi-Square test was performed (Table 5). Age was significant for the access to quality education $\left(\mathrm{X}^{2}=14.680, p \leq .0001\right)$.

\section{Access to clean water}

To determine the relationship between age and access to clean water, a Chi-Square test was performed (Table $5)$. Age was significant for the access to clean water $\left(\mathrm{X}^{2}=30.1065, p \leq .0001\right)$.

\section{Access to good housing facilities}

To determine the relationship between age and access to good housing facilities, a Chi-Square test was performed (Table 5). Age was significant for the access to good housing facilities $\left(\mathrm{X}^{2}=11.658, p \leq .0001\right)$. 
Table 5. Summary of Chi-Square Tests I

\begin{tabular}{|l|r|r|r|r|r|r|r|r|r|}
\hline \multicolumn{2}{|c|}{ Access to health care services } & \multicolumn{3}{c|}{ Access to a stable power } \\
supply
\end{tabular}

a. 1 cell (12.5\%) has expected count less than 5 . The minimum expected count is 2.82 .

a. 1 cell (12.5\%) has expected count less than 5 . The minimum expected count is 3.08 .

a. o cells (0.0\%) have expected count less than 5 . The minimum expected count is 5.90 .

Table 6. Summary of Chi-Square Tests

\begin{tabular}{|c|c|c|c|c|c|c|}
\hline \multicolumn{4}{|c|}{ Access to clean water } & \multicolumn{3}{|c|}{ Access to good housing facilities } \\
\hline & Value & df & $\begin{array}{l}\text { Asymp. } \\
\text { Sig. (2- } \\
\text { sided) }\end{array}$ & Value & Df & $\begin{array}{c}\text { Asymp. } \\
\text { Sig. (2- } \\
\text { sided) }\end{array}$ \\
\hline $\begin{array}{l}\text { Pearson } \\
\text { Chi-Square }\end{array}$ & $30.1065^{\mathrm{a}}$ & 3 & .000 & $11.65^{8 \mathrm{a}}$ & 3 & .009 \\
\hline $\begin{array}{l}\text { Likelihood } \\
\text { ratio }\end{array}$ & 32.572 & 3 & .000 & 10.503 & 3 & .015 \\
\hline $\begin{array}{l}\text { Linear-by- } \\
\text { linear } \\
\text { association }\end{array}$ & 22.084 & 1 & .000 & .021 & 1 & .886 \\
\hline $\begin{array}{l}\text { No. of valid } \\
\text { cases }\end{array}$ & 395 & & & 395 & & \\
\hline
\end{tabular}

a. $\mathrm{o}$ cells $(0.0 \%)$ have expected count less than 5 . The minimum expected count is 5.53 .

a. 1 cell (12.5\%) has expected count less than 5 . The minimum expected count is 4.73 .

\section{Discussion}

Our study sought to assess the prevalence of multidimensional poverty in Lagos State, Nigeria, using Oto/Ijanikin area as the study area. We selected indicators, such as electricity, clean water, good housing facilities, healthcare, and education, as units of analysis to determine the extent of multidimensional poverty in the study area. The results in Table 2 show the percentage of participants according to their age, gender, educational level, and employment status. As observed, 44 (11\%) respondents are between 15 and 24 years old while the majority $(231 ; 59 \%)$ of the respondents are 
between 25 and 34 years old. This is closely followed by those in the $35-44$ age bracket $(99 ; 25 \%)$ and those 45 years and above (21; 5\%). Table 2 further reveals that $200(51 \%)$ respondents are male and 195 (49\%) are female. Moreover, 122 (31\%) did not attend beyond primary school, 204 (52\%) did not attend beyond secondary school, and the remaining 69 (17\%) attended postsecondary school. At the same time, Table 2 demonstrates that 97 (25\%) are employed while 298 (75\%) are unemployed.

By implication, the study area had more youth in the workforce category, most of whom are male with secondary education and largely unemployed. This explains why poverty is widespread in the area as few of the youth have a postsecondary education and many of them are unemployed. Hence, they are unable to leave the community and get a job, which would help them stand the chance of contending with poverty. Concerning location, the majority of the respondents are from Oto: $54 \%$ of the respondents are from Oto, while $46 \%$ are from Ijanikin. The result further shows that 79 respondents were randomly selected from Ring road, Under bridge, AOCOED roundabout, Ile-Oba, and Mosalashi, respectively to give a total of 395 participants.

Table 3 shows the summary results of the questionnaire, which was aimed at assessing the dimensions and indicators of multidimensional poverty-education, health, and living standard, which we broke down into health, electricity, education, water, and housing/sanitation. As observed, the majority of the people of Oto/Ijanikin not only lack access to healthcare services, but they are also deprived of stable power supply, access to education, water, and good housing facilities. Thus, the level of deprivation is not just imagined, it is well pronounced in the community. Without access to these facilities, there is no denying that poverty in the area is multidimensional. To be sure, the deficiency is highest in the area of healthcare services (87\%) wherein the community of 32,106 registered people has one primary health center (see figure 6) ${ }^{1}$, which attends mostly to antenatal and postnatal cases. The health center is equipped with six beds, two doctors, four nurses, and two other health workers.

Another difficulty is an unstable power supply (85\%), whereby electricity is rationed-usually 2 days "on" and a day "off"-and highly irregular, with monthly bills that far outweigh the power consumed. There is also deprivation relating to housing and sanitation (77\%). A larger percentage of the houses in the community are dilapidated, uninhabitable, and filthy (see figures 4 and 5). It was also discovered that there is no roadside gutter to collect rainwater, thus leaving the environment submerged during rain. We found that limited clean water (74\%) is yet another challenge plaguing the community. Indeed, $90 \%$ of the water used for cleaning, washing, and sometimes cooking is retrieved from wells, which are often dirty and mostly without covering. This is closely followed by the deficiency of quality education (72\%) as the schools are not immune to overcrowded classrooms that threaten pupils' health. This is aggravated by poor sanitation as students must walk in floods to access their classroom whenever it rains (see figure 3). We found that, often, pupils are made to provide their furniture in the school. According to LBS (2017, p. 20), in the whole of Oto-Awori, there are 16 schools, 10,810 pupils, and 140 teachers. Therefore, there is an average of 675 pupils and 9 teachers per school, or 75 pupils per teacher.

As recorded in Table 4, multidimensional poverty is more pronounced among residents between 25 and 34 years old. This group of people should be the power source of the community, considering their age. But they are incapacitated by extensive unemployment, interlaced with poor and limited education. They, like other members of the community, do not just suffer from poor education, but

\footnotetext{
${ }^{1}$ Figures 3-6 are in the Appendix.
} 
are more susceptible to lack of access to healthcare services, power supply, good housing facilities, clean water, and quality education, in that order.

The findings of this study are supported by Akinyetun (2021) that most Nigerian youth are generally unemployed and specifically exposed to inequity and exclusion, which makes them susceptible to nefarious activities. Khan (2012) found that youth exclusion is well pronounced in many countries with rigid and conservative power structures. In what he described as "waithood" or "the blocked transition to adulthood," youth exclusion denies youth in society access to public services. Uzochukwu et al. (2020) found that increasing illiteracy, persistent unemployment, poor healthcare services, exposure to exploitation and humiliation, lack of access to public services, communal clashes, increased social vices, and insurgencies are among the drivers of social exclusion in Nigeria. According to Oxfam (2017, p. 4), the level of inequality in Nigeria is extreme while poverty has been growing at an outrageous rate. For instance, "the number and the share of people living below the national poverty line increased from 69 million in 2004 to 112 [million] in 2010, equivalent to $69 \%$ of the population."

\section{Way Forward}

\section{Social inclusion}

Social inclusion is a sine qua non for the creation of a safe and unprejudiced society in which all are qualified to benefit from economic growth. It is both a process and a result that nations of the world are struggling to institutionalize. Social inclusion is the culmination of efforts targeted at engendering equality in accessing opportunities for optimum functioning, regardless of background. As a multidimensional process itself, social inclusion is relevant in combating social exclusion, marginalization, and multidimensional poverty (Abbott et al. 2017; Rahim, 2009). Several attempts have been made toward social inclusion in Nigeria, such as Youth Enterprise with Innovation in Nigeria Programme (YouWIN), Subsidy Reinvestment and Empowerment Programme (SURE-P), and Youth Employment and Social Support Operation to provide information and communication training to youth and include them in employment networks to enable participation in emerging economic trends (Meagher, 2015; Mann \& Abdirahman, 2017).

Even though few successes were recorded, these programs fell short in achieving their purposed goals (Kelly, 2019). For instance, employment-based inclusion programs in Nigeria are often antithetical to their mandate. They fail to consult with the youth who are the targets, and, moreover, usually run afoul of proper monitoring. Other shortfalls are politicization of the selection process of recipients, political pressure, cronyism, sheer corruption, and gender imbalance. In the long run, these programs, rather than eradicate social exclusion, end up entrenching it, by disproportionately selecting candidates with political connections (Banfield, 2014; ESSPIN, 2017; Kelly, 2019; Meagher, 2015).

Nigeria needs to take the following actions in the area of social inclusion:

- Guarantee the freedom and respect for all human rights and the rule of law;

- Establish financial inclusion; promote microfinancing; implement collective access to public information;

- Institute community development;

- Ensure access to healthcare;

- Encourage gender participation;

- Begin infrastructure development;

- Promote small-medium enterprises; 
- Encourage economic growth;

- Establish employment generation;

- Combat corruption;

- Develop social intervention programs;

- Protect minority rights infrastructure and facilities;

- Participate in economic, political, social, and civic activities;

- Reverse brain drain; distribute wealth and resources;

- Improve leadership and governance;

- Institute a strong and virile civil society; and

- Promote education

(Abdullahi, 2019; Akinyele \& Abasiekong, 2018; UNDESA, 2008; Mayah et al., 2017;

UNICEF, 2015).

\section{Conclusion}

Our study undertook a general overview of multidimensional poverty in Nigeria, which was further analyzed using social exclusion theory. We attempted to evaluate the extent of multidimensional poverty in Nigeria especially about the dimensions (health, education, and living standard) and indicators of poverty (healthcare, education, electricity, clean water, and good housing) selected. The findings from our study indicated that multidimensional poverty is prevalent in Nigeria and more pronounced in the study area. It, therefore, behooves the government to promote social inclusion through education at all levels; encourage accountability and transparency in governance; drive participation in economic, political, social, and civic activities through balanced power relations; strengthen tolerance for cultural and identity diversity; and ensure the equitable distribution of wealth and resources. The results of our study theoretically support social exclusion theory as espoused by Khan et al (2015), Lenoir (1974), Rodgers et al. (1997), Room (1995), and Sen (2000). 


\section{References}

Abbott, P., Wallace, C., \& Sapsford, R. (2017). Socially inclusive development: The foundations for decent societies in East and Southern Africa. Applied Research in Quality of Life, 12, 813-839. https://doi.org/10.1007/s11482-016-9491-6

Abdullahi, M. S. (2019, March 21). Three things Nigeria must do to end extreme poverty. World Economic Forum. https://www.weforum.org/agenda/2019/03/90-million-nigerians-live-in-extreme-povertyhere-are-3-ways-to-bring-them-out/

African Development Bank Group (2015). Eliminating extreme poverty in Nigeria. Working paper series no. 223. https://www.afdb.org/fileadmin/uploads/afdb/Documents/Publications/Working_Paper_223__Eliminating_Extreme_Poverty_in_Africa_Trends_Policies_and_the_Role_of_International_Organ izations.pdf

Ajakaiye, O., Jerome, A., Olaniyan, O., Mahrt, K., \& Alaba, O. A. (2014). Multidimensional poverty in Nigeria: First order dominance approach. WIDER Working Paper Series wp-2014-143. World Institute for Development Economics Research (UNU-WIDER).

Akinyele, B., \& Abasiekong, O. (2018, October 17). \#EndPoverty: 9 ways Nigeria should address poverty. Proshare. https://www.proshareng.com/news/Nigeria\%20Economy/-EndPoverty-9-Ways-NigeriaShould-Address--Poverty/42284

Akinyetun, T. S. (2021). Youth political participation, good governance and social inclusion in Nigeria: Evidence from Nairaland. Canadian Journal of Family and Youth, 13(2), 1-13. https://doi.org/10.29173/cjfy29648

Akinyetun, T. S., \& Bakare, K. M. (2020). Identity crises and national development in Africa: An exploratory example of Nigeria and Sudan. International Journal of Political Science and Development, 8(1), 114. https://dx.doi.org/10.14662/IJPSD2020.010

Alkire, S., \& Santos, M. E. (2014). Measuring acute poverty in the developing world: Robustness and scope of the Multidimensional Poverty Index. World Development, 59, 251-274.

https://doi.org/10.1016/j.worlddev.2014.01.026

Amao, J. O., Ayantoye, K., \& Fanifosi, G. E. (2017). An analysis of multidimensional poverty and its determinants in rural Nigeria. Journal of Development and Agricultural Economics, 9(11), 303-311. https://doi.org/10.5897/JDAE2017.0857

Banfield, J. (2014). Winners or losers: Assessing the contribution of youth employment and empowerment programmes to reducing conflict risk in Nigeria. https://reliefweb.int/sites/reliefweb.int/files/resources/WINNER-OR-LOSER-final-6.2.2014.pdf

Birchall, J. (2019). Overview of social exclusion in Nigeria. K4D Helpdesk Report. Institute of Development Studies. https://opendocs.ids.ac.uk/opendocs/handle/20.500.12413/14809

Brück, T., \& Kebede, S. W. (2013). Dynamics and drivers of consumption and multidimensional poverty: Evidence from rural Ethiopia. Institute of Labor Economics (IZA) DP No. 7364. https://www.iza.org/publications/dp/7364

Dean, H. (2016). Poverty and social exclusion. In H. Dean \& L. Platt (Eds.). Social advantage and disadvantage. Oxford University Press. https://doi.org/10.1093/acprof:oso/9780198737070.003.0001

Education Sector Support Programme in Nigeria (ESSPIN). (2017). ESSPIN end-of-programme report 2017: Building lasting change. https://www.esspin.org/ESSPIN-Final-report-EOP-Report-BuildingLasting-Change-Jan2017.pdf 
Ferreira, F. H. G., Chen, S., Dabalen, A., Dikhanov, Y., Hamadeh, N., Jolliffe, D. M., Narayen, A., Prydz, E. B., Revenga, A., Sangraula, P., Serajuddin, U., \& Yoshida, N. (2015). A global count of the extreme poor in 2012: Data issues, methodology and initial results. Discussion Paper Series. IZA DP no. 9442. IZA. http://ftp.iza.org/dp9442.pdf

Garba, A. (2006, July 28-29). Alleviating poverty in Northern Nigeria [Paper presentation]. Annual Convention of Zumunta Association, Minneapolis, MN, United States.

Hills, J., Le Grand, J., \& Piachaud, D. (Eds.). (2002). Understanding social exclusion. Oxford University Press.

Kelly, L. (2019). Evidence on social inclusion programming in Nigeria. K4D Helpdesk Report 690. Institute of Development Studies. https://opendocs.ids.ac.uk/opendocs/handle/20.500.12413/14808

Khan, S. (2012). Topic guide on social exclusion. University of Birmingham: Governance and Social Development Resource Centre. http://gsdrc.org/docs/open/se10.pdf

Khan, S., Combaz, E., \& McAslan Fraser, E. (2015). Social exclusion: Topic guide. Revised edition. GSDRC, University of Birmingham.

Lagos Bureau of Statistics (LBS). (2016). Poverty profile for Lagos State. Ministry of Economic Planning and Budget.

Lagos Bureau of Statistics (LBS). (2017). Abstract of local government statistics 2017. Ministry of Economic Planning and Budget. http://mepb.lagosstate.gov.ng/storage/sites/29/2018/o6/Abstract-of-LGStatistics-2017editted.pdf

Law, B., \& Shek D. T. (2014). Beliefs about poverty. In A. C. Michalos (Ed.). Encyclopedia of quality of life and well-being research. Springer. https://doi.org/10.1007/978-94-007-0753-5 166

Lenoir, R. (1974). Les exclus: Un Français sur dix. Population, 3o(1), 180-181.

Le Van, C., Hassan, I., Isumonah, V., Kwaja, C., Momale, S., Nwankwor, C., \& Okenyodo, K. (2019). Study on marginalized groups in the context of ID in Nigeria National Identification for Development (ID4D)

Project. http://documents.worldbank.org/curated/en/922031561717650301/Study-on-

MarginalizedGroups-in-the-Context-of-ID-in-Nigeria-National-Identification-for-DevelopmentID4D-Project

Lister, R. (2004). Poverty. Polity Press.

Mann, L., \& Abdirahman, I. (2017). Connectivity at the bottom of the pyramid: ICT4D and informal economic inclusion in Africa [Paper presentation]. Connectivity at the BoP Forum, Bellagio Centre White Paper. https://bit.ly/3kWPDoX

Mayah, E., Mariotti, C., Mere, E., \& Odo, C. O. (2017). Inequality in Nigeria: Exploring the drivers. Oxfam International. https://oi-files-cng-prod.s3.amazonaws.com/nigeria.oxfam.org/s3fs-public/crinequality-in-nigeria-170517-en.pdf

McHugh, M. L. (2013). The Chi-square test of independence. Biochemia Medica, 23(2), 143-149. https://doi.org/10.11613/BM.2013.018

Meagher, K. (2015). Leaving no one behind? Informal economies, economic inclusion and Islamic extremism in Nigeria. Journal of International Development, 27(6), 835-855. https://doi.org/10.1002/jid.3117

Momodou, T. (2016, July). Definitions and measures of poverty. Devinit.

Multidimensional Poverty Peer Network (MPPN). (n.d.). What is multidimensional poverty? MPPN. https://mppn.org/multidimensional-poverty/what-is-multidimensional-poverty/ 
Multidimensional Poverty Peer Network (MPPN). (2018, November 6). National multidimensional poverty index for Nigeria. MPPN. https://mppn.org/nigeria-national-

mpi/\#: :text=For\%20Nigeria\%2C\%20the\%20share\%20of,of\%20schooling\%20and\%20school\%20att endance

Naidoo, P. (2020, March 3). Nigeria tops South Africa as the Continent's biggest economy. Bloomberg. https://www.bloomberg.com/news/articles/2020-03-03/nigeria-now-tops-south-africa-as-thecontinent-s-biggest-economy

National Bureau of Statistics (NBS). (2012, February 13). The Nigeria poverty profile 2010 report. Statistician-General of the Federation [Press briefing].

National Bureau of Statistics (NBS). (2020). 2019 Poverty and inequality in Nigeria: Executive summary. Proshare. www.nigerianstat.gov.ng

Nworgu, B. G., \& Nworgu, L. N. (2013). Urban-rural disparities in achievement at the basic education level: The plight of the rural child in a developing country. Developing Country Studies, 3(14), 128-140.

Ogionwo, T. (2016). Social problems and the rise of terrorism in Nigeria: Implications for international social work practice. Bachelor's thesis, University of Gavle. Retrieved from http://hig.divaportal.org/smash/get/diva2:897006/FULLTEXTo1

Oxford Poverty and Human Development Initiative (OPHI). (2018). Global multidimensional poverty index 2018: The most detailed picture to date of the world's poorest people. Oxford Poverty and Human Development Initiative.

Oxfam International (2017). Inequality in Nigeria: Exploring the drivers. Oxfam International. https://wwwcdn.oxfam.org/s3fs-public/file attachments/cr-inequality-in-nigeria-170517-en.pdf

Rahim, S. (2009, November). The African common position on social integration and the social policy framework for Africa [Paper presentation]. United Nations Department of Economic and Social Affairs Expert Group Meeting Practical Strategies to Promote Social Integration: Lessons learned from existing policies and practices. http://www.un.org/esa/socdev/egms/docs/2009/Ghana/Rahim.pdf.

Rodgers, G., Gore, C., \& Figueiredo, J. B. (Eds.). (1997). Social exclusion: Rhetoric, reality, responses. International Labour Organization.

Room, G. (1995). Poverty and social exclusion: The new European agenda for policy and research. In G. Room (Ed.). Beyond the threshold: The measurement and analysis of social exclusion (pp. 1-9). Policy Press.

Sambe, M. (2019, August 13). Nigeria is in multidimensional poverty. Stears Business. https://www.stearsng.com/article/nigeria-is-in-multidimensional-poverty

Sen, A. (2000, June). Social exclusion: concept, application and scrutiny. Social Development papers 1. Asian Development Bank.

Silver, H. (1994). Social exclusion and social solidarity: Three paradigms. International Labour Review, 133(5-6), 531-578.

Spicker, P. (1993). Poverty and social security: Concepts and principles. Routledge.

Tiemann, S. (1993). Opinion on social exclusion, Official Journal of the European Communities, 36, 48-54. https://eur-lex.europa.eu/legal-content/EN/TXT/PDF/?uri=OJ:C:1993:352:FULL\&from=EL

United Nations Development Programme (UNDP). (2010). The real wealth of nations: Pathways to human development. Human Development Report 2010. UNDP. 
United Nations Development Programme (UNDP). (2018). National human development report 2018: Achieving human development in North East Nigeria. UNDP.

United Nations Department of Economic and Social Affairs (2008). Creating an inclusive society: Practical strategies to promote social integration. https://www.un.org/esa/socdev/egms/docs/2008/Parisreport.pdf

United Nations Children's Fund (2015). 2014 annual results report: Social inclusion. United Nations Children's Fund.

Uzochukwu, B. S., Okeke, C. C., Ogwezi, J., Emunemu, B., Onibon, F., Ebenso, B., Mirzoev, T., \& Mir, G. (2020). Exploring the drivers of ethnic and religious exclusion from public services in Nigeria: Implications for sustainable development goal 10. International Journal of Sociology and Social Policy. https://doi.org/10.1108/IJSSP-02-2020-0036

World Bank (2016). Poverty reduction in Nigeria in the last decade. World Bank. https://openknowledge.worldbank.org/handle/10986/25825 


\section{Appendix}

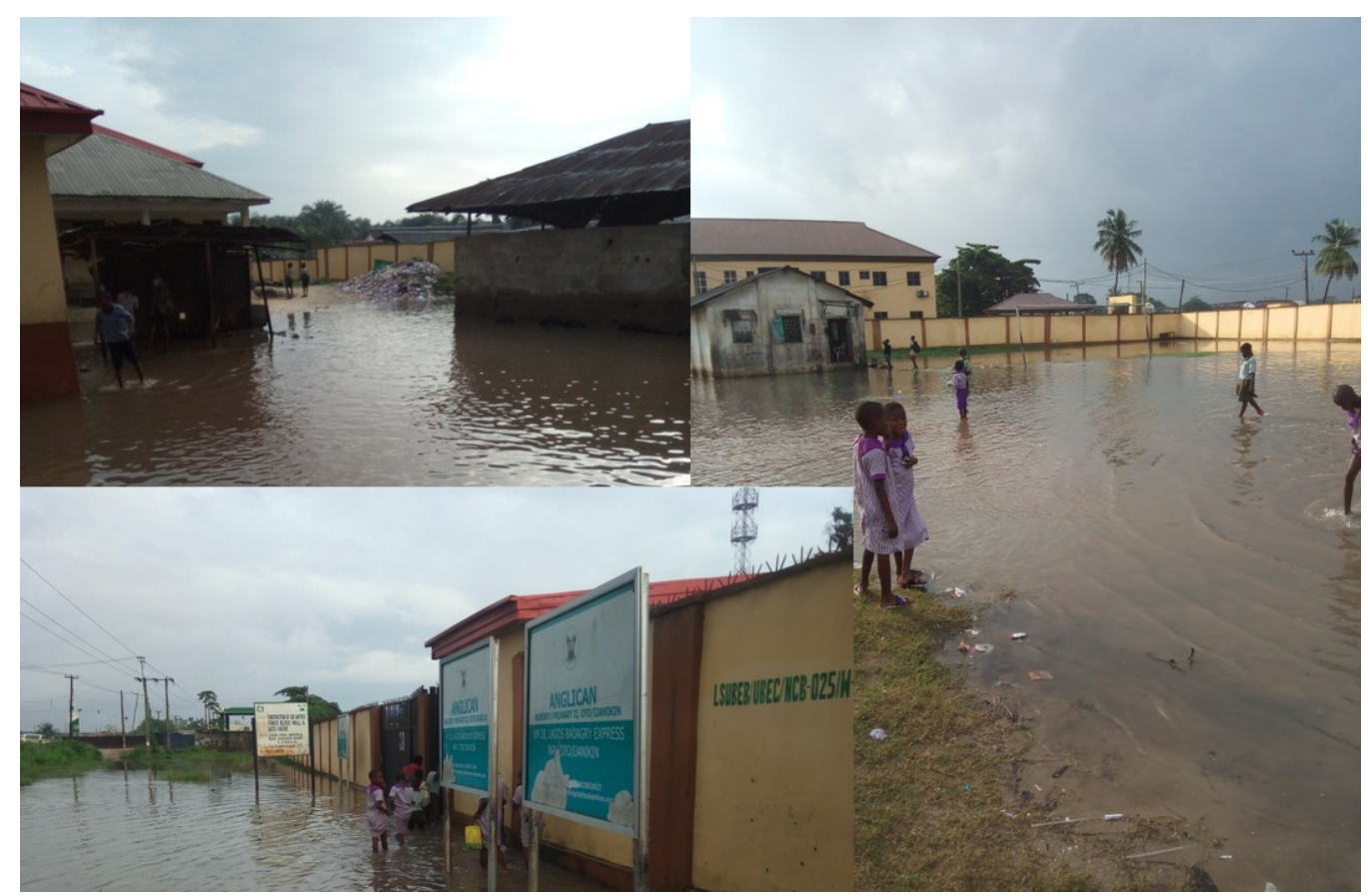

Figure 3. Anglican Primary School, Ijanikin During the Rainy Season

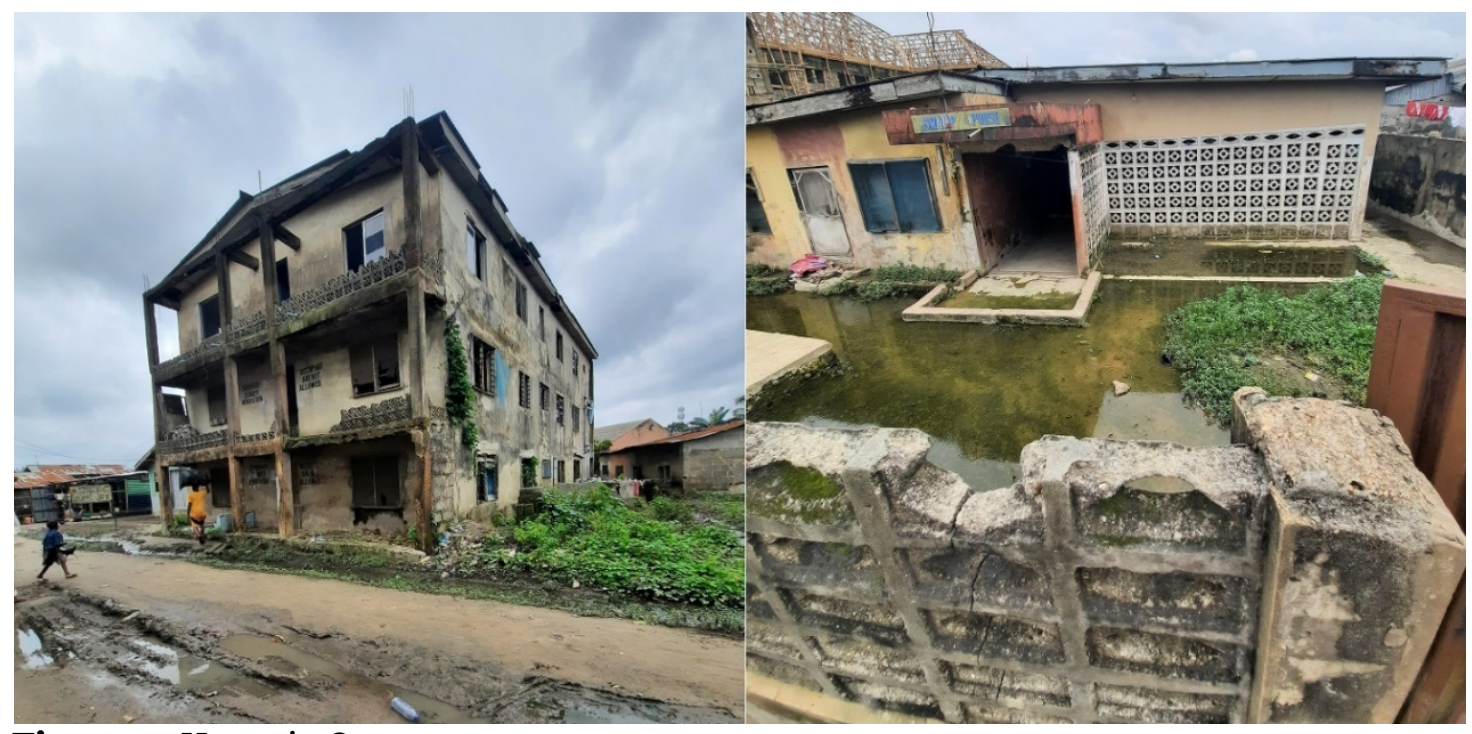

Figure 4. House in Oto 


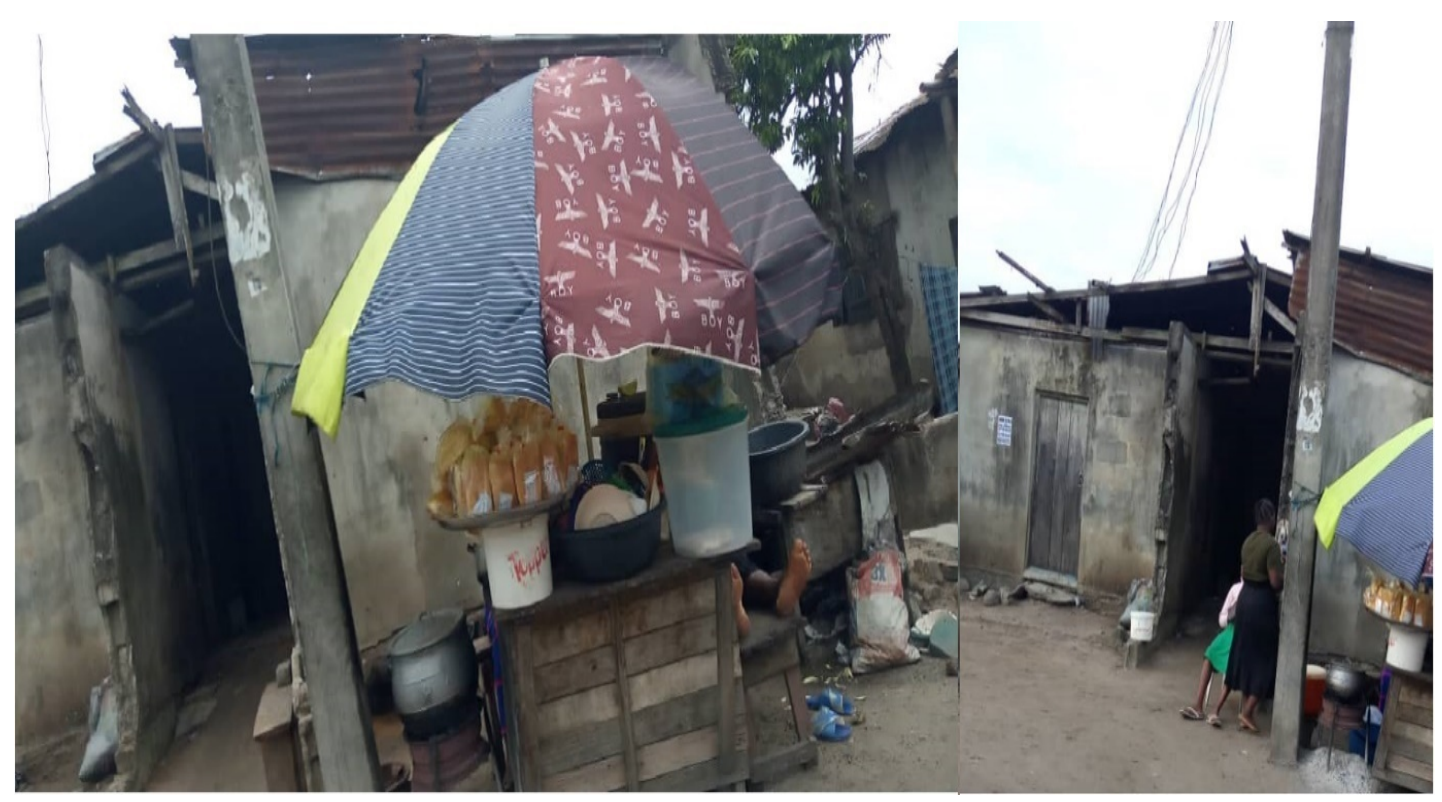

Figure 5. House in Ijanikin

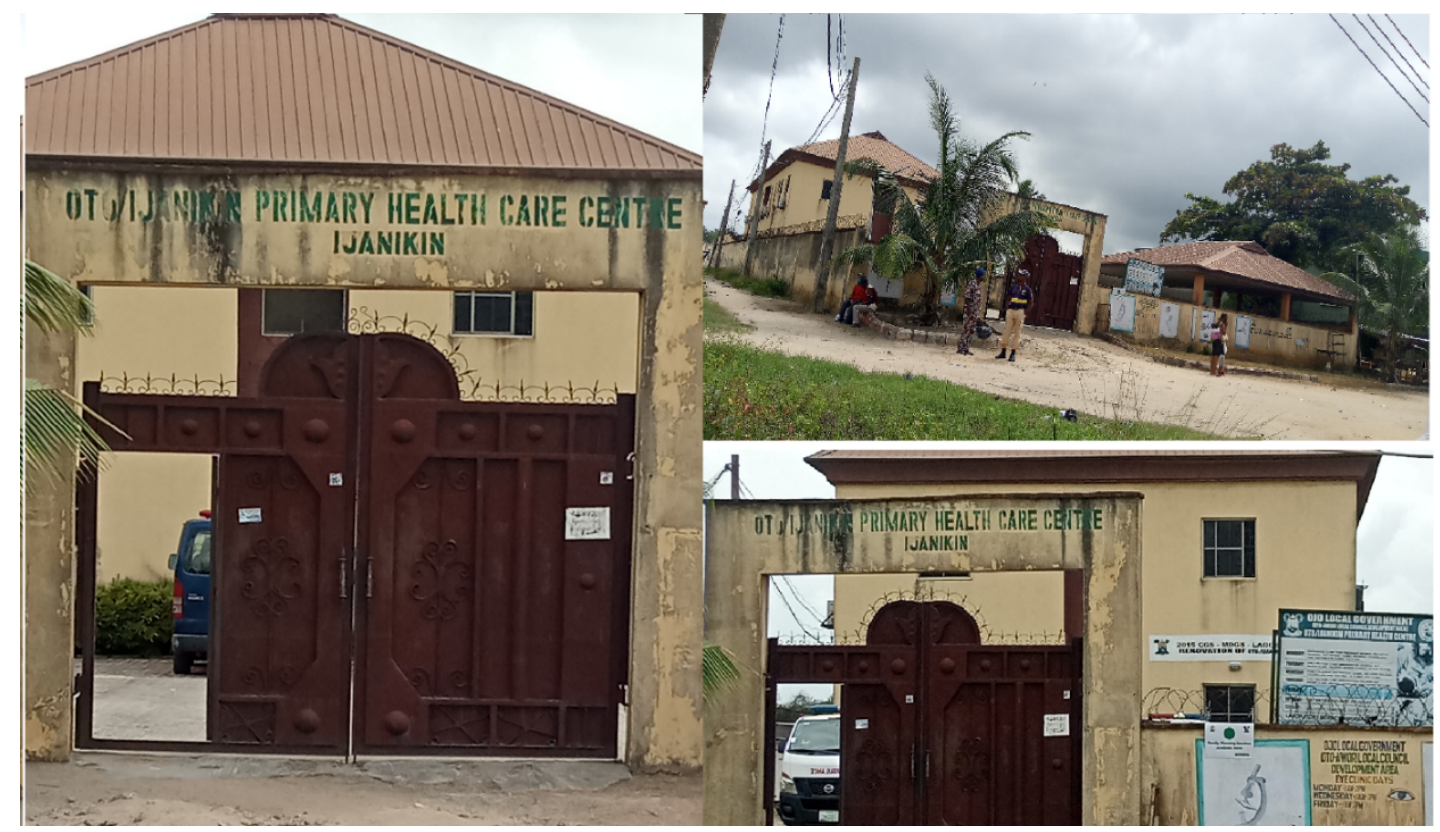

Figure 6. Oto/Ijanikin primary health care center

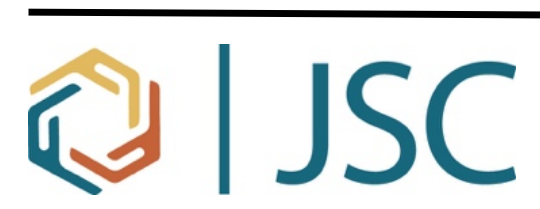

The Journal of Social Change, sponsored by Walden University, welcomes manuscripts focusing on interdisciplinary research in social change that improves the human condition and moves people, groups, organizations, cultures, and society toward a more positive future. 